\title{
"Even the NGOs Never Talk About Ufiti [Witchcraft]": a Decolonial and Feminist Cultural Psychological Analysis of Individualized Development Clashing with Communal Ways of Being
}

\author{
Johanna Sofia Adolfsson ${ }^{1}$ (D) . Sigrun Marie Moss ${ }^{2}$
}

Received: 3 July 2020 / Revised: 16 April 2021 / Accepted: 15 May 2021

(c) The Author(s) 2021

\begin{abstract}
Conducting a multi-sited psychology study on how Malawian participants perceive Westernoriented non-governmental organizations' (NGOs) gendered development approaches, it became apparent that perceptions of $u f i t i$ (the Malawian term for what loosely translates as witchcraft in English) — and its gendered inclination — was highly relevant. As in many parts of the world, people in Malawi may relate themselves and their social world in connection to spiritual and supernatural dimensions, manifested in practices and discourses often closely linked to communal norms and values. Many international NGOs in Malawi run individualized development initiatives, often particularly focusing on women and girls' personal empowerment. When local communal ways of experiencing and knowing are not taken account for in the NGOs' interventions, this indiviualized approach can spur interpersonal resentment, and in worst-case ufiti assaults. This article explores the link between individualized development incentives and perceptions of ufiti. Using decolonial and feminist cultural psychology as a lens, we ask how the individualized focus of the NGOs plays out in Malawi, and what negative and unintended consequences individualized interventions can lead to. Our results indicate the need for contextually grounded and informed development approaches, to avoid that effort to empower individual women and girls lead to their disempowerment, social disruption, and ufiti accusations and assaults. The article speaks to the need for decolonial and feminist cultural psychological approaches that consider subjective intentional worlds.
\end{abstract}

Keywords Decolonial feminist cultural psychology $\cdot$ Coloniality $\cdot$ Individualized gendered development · Spiritual othering · Ufiti . "Witchcraft"

Johanna Sofia Adolfsson

johanna.adolfsson@sum.uio.no

1 Center for Development and the Environment, University of Oslo, Problemveien 7, 0315 Oslo, Norway

2 Department of Psychology, University of Oslo, Problemveien 7, 0315 Oslo, Norway 
Cultural psychologist Shweder (1990, p. 1) talks about intentional worlds, i.e., how "psyche and culture...require each other... and jointly make each other up." What is regarded as justified, valid, and true is socially and culturally constructed and decided on as "social facts" (Shweder, 2006). Accordingly, individuals involved in the same socio-cultural realities construct, make meaning of and manifest particular conceptions, which are social facts of "reality" (Shweder, 2006). Looking at two sets of intentional worlds (with extensive variation), the Malawian and that of many international non-governmental organizations (NGOs) operating in Malawi, these have a different overarching starting point: communalism and individualism, respectively.

Development practitioners must acknowledge and incorporate the specific intentional worlds of the cultural context, if not, they risk inflicting unintended ramifications on recipients of their interventions. Malawian participants in our study spoke of the individualized focus of most NGOs as "moving some individuals in the community forward rather than all," which often broke with their communal ways of life (see Adolfsson \& Moss, 2021). The breeches, our participants told us, often resulted in suspicion, interpersonal resentment, enmity, and envy, which they again on the other hand linked to perceptions and articulations of ufiti. Ufiti is commonly translated to what English missionaries, colonial administrators, and Western academics rather ambiguously termed "witchcraft" (Lwanda, 2005; Mbiti, 1990; Tembo, 1993). The pervasiveness of Malawian ufiti articulations and beliefs is well documented; the immense fear of enmity, accusations, and assaults related to it permeates the social fabric and everyday life of many (Ashforth, 2015; Englund, 1996, 2007; Mgbako \& Glenn, 2011). An extensive survey conducted both in rural and urban Malawi revealed that $87 \%$ of the interviewed household heads stated ufiti was present and increasing in their societies (Chilimampunga \& Thindwa, 2012). The violence resulting from ufiti is considered just as real and harmful as other forms of assaults and is directly linked to matters of life and death (Chilimampunga \& Thindwa, 2012). As with other inequalities, Malawian women are among the groups most exposed of ufiti-based violence (Chilimampunga \& Thindwa, 2012; Mgbako \& Glenn, 2011). Women are also the key targets for many individualized empowerment initiatives in Malawi, making them potentially even more exposed to unintended, negative ramifications of NGO interventions.

Generally, when talking to participants involved in NGO activities they are glad for the support. They do however question elements of the interventions-in terms of their organization and fit with the local communities (see Adolfsson \& Madsen, 2020; Adolfsson \& Moss, 2021). Many participants in our study link NGO interventions, which typically focus on some in the community rather than all, to jealousy. Many also link jealousy to perceptions of ufiti. They do however not link the two; very few of the participants say outright that the NGOs development initiatives like individualized gendered empowerment approaches, directly lead to ufiti accusations and assaults. Based on our analysis, we make the connection between these two. Based on a multi-sited fieldwork in Malawi (2016/2017), we use decolonial and feminist cultural psychology as a lens, asking how the individualized focus of the NGOs plays out in Malawi, and what unintended negative consequences the interventions can lead to. We agree with many of the participants that the NGOs interventions can have positive outputs. However, our material serves a powerful illustration of how limited awareness - or ignorance - of people's cultural context and intentional world may end up disempowering and marginalizing the very same individuals and groups that these NGOs seek to empower. Our aim with this article is to encourage psychologists as well as global development practitioners to include and engage with the specific contexts and intentional worlds in which we intervene, to avoid unintended negative consequences of our actions. 


\section{Decolonial and Feminist Cultural Psychology}

A decolonial and feminist cultural psychology framework provides tools to challenge dominant assumptions that reinforces classed, racialized, and gendered status quos by encouraging tolerance and acknowledging Others' as well as our own ways of being, seeing and knowing as equally embedded in culture (Adams et al., 2015). That is; while "a weed is a weed is a weed" (Shweder, 1990, p. 2) in some cultural contexts, it is not in others, and what is regarded as good, true, effective, and fascinating in life, should also be regarded as equally un-fixed and un-universal. Yet, dominant Western assumptions of what counts as good and true are continuously largely promoted as standard norms (see Adjei, 2019; Bulhan, 2015; Kessi \& Boonzaier, 2018; Nwoye, 2017). This bias not only preserves and premises hegemonic knowledge production but also has physical and psychological consequences for people, in terms of pathologization and marginalization of their ways of being (see Davar, 2020; Dhar, 2020; Nwoye, 2013). Thus, an important objective of a decolonial and feminist cultural psychological perspective is to challenge such dominant assumptions, and to illuminate and promote alternate - and equally real — ways of understanding human ways of living in and making meaning of the world (Adams \& Estrada-Villalta, 2017; Kurtis \& Adams, 2013). A particularly important aspect in terms of our study, is decolonial perspectives' aim to reveal patterns of coloniality that promote Western individualism (Adams et al., 2017). Coloniality and Western individualism is understood as both products and sources of imperial and colonial exploitation and violence (Adams et al., 2017). By enabling accumulation, expansion, social- and economic development, personal growth and self-actualization, EuroAmerican colonialism and its patriarchal power structures have perpetually shaped and promoted Western understandings of gendered individual selfhoods, while disregarding other ways of being (Bulhan, 2015; Mies, 2014). Coloniality is thus a continuation of colonial and patriarchal ways of understanding and seeing the Other. As such, Western individualism and the practicing of individual selfhoods are inherent parts of the matrix that decolonial theorists call the coloniality of power, knowledge, and being (see Maldonado-Torres, 2007; Mignolo, 2007; Quijano, 2000). To decolonize coloniality Adams et al. (2015, p. 228) suggest a denaturalization approach; "turning the analytic lens" to "re-think the ways of being that masquerade as natural standards" in many Western psychological perspectives. Drawing on these concepts and approaches, and especially concerning the coloniality inherent in Western individualism, and our Malawian participants' accounts of NGOs individualized and gendered development initiatives, we wish to illuminate how dominant assumptions of individualism - here promoted by international NGOs - are inconsistent with and potentially dangerous for people who experience and organize their worlds in other ways.

\section{The Phenomena of Ufiti}

In rural Malawi-as many places elsewhere-people often rely on communal and reciprocal responsibilities and social norms of equality which make up the social glue that protect them from the harmful effects of poverty (Ferguson, 2006; Lwanda, 2005). Anti-social, selfish, and greedy behavior is, on the other hand, understood as vicious acts of ufiti and seen as directly conflicting with communal norms and therefore directly dangerous for the wellbeing and existence of individuals and groups (Ferguson, 2006; Golooba-Mutebi, 2005). Growing social inequality is often seen as results of greed and 
selfishness, fueling suspicions of people having used ufiti to unjustly progress and profit at the cost of others (Lwanda, 2005). This in turn, fuels social tensions, enmity, and in extension; ufiti-related accusations and assaults (Chilimampunga \& Thindwa, 2012; Mgbako \& Glenn, 2011). As such, ufiti accusations and assaults may be understood as a response to, and acts of resistance and protection against the pervading threat of ufitibased violence (Golooba-Mutebi, 2005).

The most common types of ufiti accusations are linked to people being accused for having used ufiti and magic forces to harm others (Lwanda, 2005). Individuals accused and assaulted for having used ufiti-spells on others face physical, social, psychological, economic, and sexual-violence in terms of beatings, social exclusion, psychological trauma, impoverishment, and sexual abuse (see Chilimampunga \& Thindwa, 2012; Mgbako \& Glenn, 2011). As elsewhere-and as with most gendered inequalitieswomen are among the most exposed to the harmful consequences of ufiti-especially in terms of being blamed for being the source of it (Federici, 2018; Mgbako \& Glenn, 2011). This is particularly interesting regarding many NGOs' heavy focus on women and girls' individual empowerment. Given that successful individuals—and especially women-are more likely to be charged of having used ufiti to progress at the expense of others (Golooba-Mutebi, 2005; Leistner, 2014), individualized development initiatives increasing inequality may (however unintentionally) also increase women and girls exposition to ufiti-based violence. Despite the documented link between individualized development initiatives and increased perceptions of ufiti (see Leistner, 2014; Smith, 2008), Chilimampunga and Thindwa (2012, p. 77) maintain, "Very few NGOs are involved in the witchcraft [ufiti] problem." Talking to the chief of the two rural villages in which we conducted fieldwork, he confirmed this, telling us "ufiti is still here ... even the NGOs never talk about ufiti."

\section{Ufiti and Psychology}

While ufiti is characterized as a spiritual, supernatural, social, and psychological phenomena (Chilimampunga \& Thindwa, 2012), African scholars warn that particularly Western psychological perspectives fail to acknowledge the central role of spirituality, the supernatural, and "the impact of other forces" in African everyday life (see Nwoye, 2015, p. 99; Ogbonnaya, 1994; Ratele, 2017). For instance, Holdstock (2000) maintains that dominant Western psychological approaches have regarded these "other" forces, like ufiti beliefs as symptoms of mental illness, delusion, and/or superstition. Furthermore, scholars hold that dominant psychological approaches based on assumptions of context-free individual agency, self-expansion, and actualization, largely conflict with African perceptions of agency, morality, community, and the self (Baloyi \& Ramose, 2016; Mkhize, 2004). When the self and its belongingness is experienced as "relationally connected to others in a network of embedded interdependence" (Adjei, 2019 , p. 490), strives for individual independency and selves that are abstracted from context, may result in social ruptures and communal disharmony (Adams et al., 2017). As such, unburdened individualism is in direct conflict with communal norms and morals of reciprocity (Sagner \& Mtati, 1999). Accordingly, practicing individuality and self-actualization may result in detrimental consequences for people. 


\section{Spiritual Othering}

The Kenyan Anglican priest and professor of theology Mbiti (1990) states,

Every African who has grown up in the traditional environment will, no doubt, know something about this mystical power which often is experienced, or manifests itself, in form of magic, divination, witchcraft and mysterious phenomena that seem to defy even immediate scientific explanations (p. 191).... In popular usage the term 'witchcraft' is employed to designate the harmful employment of mystical power in all its different manifestations (p. 199).

Beliefs in the supernatural and spiritual are not restricted to Africa (see Makhubela, 2016), rather the perception of spiritual entities like angels, demons, and Satan is a world phenomenon (Ivey \& Myers, 2008). Yet, when applied to Africa and Africans, the larger part of Eurocentric literature on "witchcraft" have perpetually ignored, belittled, and distorted African experiences of spirituality and the supernatural (Mbiti, 1990; Murrey, 2017). By reinforcing racist perceptions of "“ignorance," "backwardness," "dark continent," "primitive," "uncivilized," "superstitious," "undeveloped"” (Tembo, 1993, p. 1), further manifest prejudiced and humiliating simplifications of African understanding of life (Ferguson, 2006; Mbembe, 2001; Mbiti, 1990). The racialized Othering of African ontologies and its grim consequences could as the Malawian scholar Lwanda (2005, p. 241) states, have been prevented:

Put simply, ufiti in its classical form equates to the devil. Had Christian missionaries accepted that ATRs [African Traditional Religions] had concepts of good (God) and bad (evil/devil), the whole subsequent discourse in which missionaries saw all ATRs as 'pagan' or 'heathen' devil worship would have been avoided

However, as Murrey (2017, p. 158) maintains, spiritual Othering functioned as the "ideological orientation(s) and moral framework(s) for enslavement, colonialism and imperialism" profoundly connected with both the construction and conception of racial hierarchies, patriarchy, and the argument of the civilization-mission. While Malawi-like other African states-now longer are formally colonized, coloniality remains, among others in how hegemonic Eurocentric understandings of how forces of spirituality and the supernatural are to be interpreted and understood.

\section{Contextual Background}

Malawi, often referred to as "the warm heart of Africa," is a small landlocked country in the east sub-Saharan region. The former British protectorate gained its independence in 1964 and followed by 30 years of dictatorship the country instituted democracy in 1994 (Tambulasi \& Kayuni, 2005). Malawi's colonial past, post-colonial present, and social and geographical context has left the country poor, rural and largely dependent on foreign aid (Swidler \& Watkins, 2017). As Lwanda (2006, p. 527) asserts, "Colonial grants have been replaced by postcolonial loans and grants, creating a debt-burdened donor-dependent state." About $85 \%$ of the population live in the "very rural" where basic infrastructure such as clean water, electricity, hospitals, nearby schools, and roads are largely missing (Edriss \& Chiunda, 2017; IMF, 2017; NSO, 2019). Although poverty strikes the whole society, women are hit the hardest (Anderson, 2015). 
Women are more vulnerable to gender-based violence and sexual insecurity; they have less access to food, medicine, water, education, and upward mobility (Anderson, 2015; Johnson, 2018).

The Malawian state has, for decades, tried to improve development and reduce poverty by focusing extensively on empowerment of women and girls (Classen, 2013; The Ministry of Gender, 2013). In the wake of the implementation of global UN gendered agendas (such as the Millennium Development Goal 3 and the Sustainable Development Goal 5), the focus on Malawian women and girls' gender equality and empowerment have further increased (UNDP, 2016), fronted by an endless number of NGOs. These initiatives are often focused on individual empowerment, like women and girls' education (Pot, 2019), entrepreneurial life-skill courses and vocational training (Johnson, 2018), designed to "empower people to achieve their goals for themselves" (Swidler, 2013, p. 684).

\section{Methodological Framework and Fieldwork Context}

The data for this article is based on three field-settings: a peri-urban township in the capital Lilongwe, two rural villages in a southern Malawian district, and urban Lilongwe. The data material is primarily based on informal interviews, focus group discussions (hereafter abbreviated as FGDs) and in-depth interviews. The first author collected much of the data material with help from a Malawian research collaborator "Wanda". Her extensive experience with ethnographic fieldwork, translation, and transcription proved invaluable. Wanda speaks Chichewa and Chiyao, the major languages in our research sites. The fieldwork was conducted over an 11 months research stay divided in three periods, between September 2016 and December 2017. In total 55 informal interviews, 30 in-depth interviews and 5 FGDs were conducted.

\section{Research Sites and Data Collection}

\section{The Township}

Initially having little knowledge of the phenomena of $u$ fiti, the first author became aware of its pervasive character during her first fieldwork, in a township outside the capital (hereafter referred to as "the township"). Living in the township together with Wanda, she learned how much of everyday matters were intricately related to peoples' fear of ufiti-based violence. While her preliminary research purpose was to study how NGO approaches on "women and girls' empowerment and gender equality" was understood by Malawians as well as the NGOs working in the country, the emerging matter of people's fear of ufiti accusations and assaults further implicated this issue. When discussing potential ways of learning more about the ufiti universe, Wanda suggested that she could listen to and record the daily and nationally broadcasted news program Nkhani za m'maboma ("news from the districts"), which frequently reported on ufiti-related incidents. Accordingly, every evening for two months, Wanda listened to the program, transcribed, and translated this content from Chichewa to English. These reports together with national newspapers and everyday discussions with Wanda, neighbors, bike-taxi drivers, water-fetchers, construction workers, venders and others formed the first author's initial data, and her understanding of ufiti and its consequences. This data was only used to inform the first author, however, many stories 
later showed to resemble the data gathered by Wanda and her in their following fieldworks. Additionally, Wanda conducted 16 informal interviews in the township with respectively ten men and six women. As these informants were not directly involved in NGO-initiatives Wanda presented the study as a study on gender equality, empowerment, and perceptions of $u$ fiti. After participants gave their consent, the interviews often took place whilst Wanda participated in the interviewee's daily duties. These interviews generally lasted 30-60 min and focused on topics regarding "development," "gender-equality," "empowerment," "gender-roles," "ufiti." Wanda took notes there and then, which she afterwards revised and translated.

\section{The Rural Villages}

The second fieldwork was conducted in a rural district in the south of Malawi (hereafter referred to as "the rural villages"). Frequent reports on ufiti-related incidents in this region were reported in the media, and in addition, the district was highly targeted by NGOs with women and girls' empowerment-approaches. Thus, this fieldwork was conducted to get at people's lived experiences with NGO interventions and the phenomena of ufiti. We selected the specific research site (and organizing the required permissions for research) in cooperation with regional authorities and the Traditional Authority (hereafter called "the chief") of the two neighboring villages in question. As the head of both villages, the chief informed the community members of the research project.Villagers generally live off small-scale farming and piecework; they cook on wood and have little or no access to electricity. Families are generally large with up to eight children. Few of the participants had finished school and some had never enrolled. The majority struggled to cover necessities like food, clothes, medicine, and school fees. The participants were between 18 and $50+$, and 24 women and 10 men. Participants reported that many NGOs had projects in the villages, and significantly, for our study, they reported that most NGO projects targeted women, especially young women, and girls' school attendance. The people in these villages had first-hand experiences with NGO-initiatives. Again, it is important to emphasize that the participants at large are happy with the NGOs being present in Malawi and want more-not less-assistance. In line with this, the project sought to get at participants' experiences of NGOs and did not invoke a positive nor negative/critical view of the NGOs in our discussions and data collection.

Being an mzunga-directly translated as wealthy, white European woman (Paass, 2016) - the first author and Wanda (an educated English speaking Malawian) had to establish trust, and ensure that the research project was not mistaken for one of the many NGOinitiatives in the area. Wanda suggested that she would work in the villages (yet living elsewhere) and visit village households daily for 14 weeks, prior to the arrival of the first author. These daily visits gave Wanda the possibility to introduce herself, the project, and us and bit by bit accustom the community members to the intention of the study and to place it apart from the NGOs operating in the area. Wanda conducted 34 informal interviews with one representative from every household in the two villages. The participants were informed of the study's overarching objective as research on their understanding of "NGOs," "development," "gender equality," "empowerment," and "cultural practices" ("cultural practices" was introduced as an encouragement and a way to get to talk about specific cultural contextual articulations and discourses-such as perceptions of ufiti). All participants asked said yes to participate. As an experienced and skilled research assistant trained in ethnographic methods, Wanda's approach was not guided by a specific interview 
schedule, but rather based on natural context, in which the topics and concepts described above were evolved and discussed organically. By simply staying in the community over time, observation becomes part of everyday life involvements, and informs the study of the holistic as well as the particularities of the communities. Wanda took extensive notes, transcribed these in Chichewa, and then translated them to English.

On the arrival of the first author, a sample of participants from the informal interviews were invited to partake in one of five FGDs. Two FDGs were conducted with only women, two with mixed-gender young adults and one with only men. All FGDs had five to six participants. After each FGD, one or two particularly active participants were invited to an in-depth interview in which we elaborated more thoroughly on the discussed topics. The interviews and FGDs were open-ended, semi-structured, and guided by questions related to "development," "gender-equality," "empowerment," "marriage and divorce," "schooling and dropping out of school," "NGOs," "cultural practices," "perceptions of ufiti." All concepts-except ufiti-are widely used by NGOs conveying empowerment approaches, and therefore worked as encouragement for the discussions. All participants asked to be interviewed agreed. Six such in-depth interviews were conducted, with three men, three women, aged between 18 and 50+. All FGDs and in-depth interviews were conducted in the community building and lasted between $30 \mathrm{~min}$ and $1 \mathrm{~h}$. All were recorded and transcribed directly after, in a collaborative effort by Wanda and the first author.

\section{Urban Lilongwe}

Based on the experiences from earlier research sites, the first author used the urban/ Lilongwe fieldwork to build a more thorough understanding of the intersection of development policy and practice, regarding gender-equality and empowerment initiatives (individualized) development approaches and perceptions of $u$ fiti. By interviewing civil servants, health workers, international and national NGO workers, foreign donor agency representatives, taxi- and tuk-tuk drivers, gardeners and others, this last fieldwork added how urban working class, educated elite- and middle class Malawians as well as international development workers understand and negotiate the presence of ufiti. None-of the participants in this fieldwork stated that they were beneficiaries of NGO-interventions. 24 interviews were conducted. Participants were invited to interviews through snowballing via mutual friends, and via mail. Age of participants varied from 20 to 60 years. The first author alone did all interviews in this fieldwork in English. She presented the research project as a study of NGOs work with gender-equality and women and girls' empowerment in Malawi. Interviews lasted between $30 \mathrm{~min}$ and two hours. The semi-structured open-ended interview guide for this fieldwork draws on the same topics and concepts as before described. In addition to earlier fieldworks, here, the first author had the possibility to ask NGO-representatives directly about their understanding of perceptions and fear of $u$ fiti.

\section{Ethical and Methodological Considerations}

The National Commission granted ethical clearance and research permits for Science and Technology in Malawi (NCST). A research permit was also ensured from Norway. Informed consent and anonymity were ensured. All participants were informed of the study's objective. 
The fieldwork settings presented the main challenges for the first author. Being an mzunga, a word fraught with colonial connotations, made her presence-especially in the township and the rural villages - a symbol of money and privilege, and as such, a symbol of colonial oppression and coloniality. A positionality that probably affects what and how people have shared information with her, and how and what she has experienced and understood different contexts. These aspects ultimately also challenge our meaning-making of the data. Thus, our analysis should be read as our co-constructed interpretations of social, spiritual, and supernatural phenomena in rural and urban Malawi. Yet, Wanda's experience with ethnographic fieldwork, her knowledge of social norms and cultural codes, her large network as well as her warm personality proved key. Underscoring the value of collaborating with local colleagues, and the importance of their expertise in getting access to situated knowledge (Moss \& Hajj, 2020; Segalo \& Fine, 2020).

\section{Analysis and Results}

All data was analyzed using inductive thematic analysis (Braun \& Clarke, 2006), where we position ourselves within a social constructionist perspective (Burr, 2015). Thus, we regard our participants' accounts as subjective, nevertheless valid. We see meaning as co-constructed by the diverse positioning in the three fieldworks, together with the co-construction of meaning by global policymakers, international donors, NGOs, and Malawian media within the wider development discourse. This stance is a valuable framework, insisting, "the ways in which we commonly understand the world, the categories and concepts we use, are historically and culturally specific" (Burr, 2015, p. 4). Thus, we also acknowledge the co-construction of meaning and positioning that occurs between the participants, Wanda, and us as authors.

The material was repeatedly and thoroughly read and coded by both authors. While reviewing the data we categorized codes and patterns and constructed themes based on recurrent topics, concepts, and discussions significant to our research questions; asking how the NGOs individualized development approaches plays out in Malawi and what unintended negative consequences the interventions can have. When reading the material we came to focus on the consequences of individualized development approaches on the one hand, and perceptions of ufiti on the other, and we were interested in the link between these. In most of the data, this seemed connected via jealousy. We thus started looking specifically for instances of individualism, communalism, and consequences of this clash. We divided the analysis into two main themes. First, individual development meets communalism. This seeks to establish the first part of the link, namely that individualized initiatives can lead to interpersonal resentment and jealousy. The second theme we have constructed is perceptions of ufiti, and NGOs individualized approaches. Exploring the second part of this two-step link between individualized initiatives and articulations of $u$ fiti, focuses on how jealousy can lead to $u$ fiti beliefs, and speaks to the focus of the paper, both on how the individualized focus of the NGOs plays out for our participants, and what unintended, negative consequences the interventions can lead to. The coloniality of individualism and spiritual Othering, which ignores the Other's ways of being and seeing the world is evident here. 


\section{Theme 1: Individualized Development Approaches Meets Communalism}

This first theme relates to the unintended consequences of individualized—and often gendereddevelopment approaches, and we have divided this into two subthemes: individual development, namely "Moving some forward" and "Jealousy."

\section{Subtheme 1.1. Moving Some Forward}

The rationale for individualized and gendered development initiatives such as women's empowerment is based on the assumption that empowerment incentives work as a means to reduce poverty by promoting self-sufficiency, self-actualization, and female entrepreneurship (Adjei, 2015; Rutherford, 2018). In the rural villages, this rationale frequently collides with communal values. Whilst participants in these villages define development as "moving forward together"; the NGOs operating there, on the other hand, are singling out specific beneficiaries, which participants understand as only "moving some forward" (see Adolfsson \& Moss, 2021). Asale, a mother of four from the rural villages, expressed frustration over the NGOs creating inequalities. She talked about one specific NGO donating potato seeds, saying, "Mostly the local NGO workers only donate to the ones that they know so it does not reach all, had it been that it went through the chief, maybe then everybody would have received." Here the singling out of a few beneficiaries stands as contrary to everybody receiving. This sentiment was echoed throughout the conversations in the rural villages. When NGOs target certain people in a community for individual development (give money for school fees, enlist participants for vocational-skills training), this is often perceived as unfair advantages, which can create suspicion and interpersonal tension.

Women and girls are often especially focused on by the NGOs, which was mentioned frequently in the interviews. Bomani, a father of five boys and three girls from the rural villages, listed the six NGOs that at the time were targeting girls' school attendance, explaining, "this [NGO] are sending girls to school, they send teen mothers back to school" and "this [another NGO] are paying school fees for all the girls but not the boys." Talking to young adults in one of the mixed-gender FGDs in the rural villages, Tambo told us "here in the village, the NGOs normally focus on girls only, while boys are not being focused on. It is the NGOs' decision to just focus on girls." Bomani and Tambo does not say whether it is good or bad to focus only on girls. However, participants in one of the young adult FGDs told us "it is the decision of the NGOs to just focus on girls", explaining that the boys who are not being focused on, and therefore do not go to school "they do some piecework, and others they just walk around and start smoking chamba [locally grown marijuana]." The participants in this FGD thought it would be best to focus on both girls and boys, women and men. Even though many of the women in the villages supported the focus on the girls (see Adolfsson \& Moss, 2021), the "NGOs' decisions" may have a large impact over people's lives, as some of their decisions may be seen to increase inequalities.

There are however ways of experiencing individual prosperity without that being problematic. This, several participants across the field settings explained, depends on whether the progress or prosperity is "sudden" and/or "inexplicable" or not. Melody, a 19-year-old girl from the rural villages, among the few young adult participants still attending secondary school, told us that after graduating she wanted to become a teacher. When asked if people can become jealous of those attending school, Melody said yes, however, telling us that this would not happen with her "because those who dropped out, they know that I have 
suffered to finish school, so they can't be jealous." This account resonates with Lwanda's (2005) analysis on how explicable and transparent advancement is understood as a fair way of prospering that seldom sparks jealousy. Melody's hard work and the sacrifices involved in her schooling allows the community to see the effort she has put in, and the reasons for her progress are thus understandable.

\section{Subtheme 1.2. Jealousy}

As seen above, individual success that is perceived as "sudden," "inexplicable," and "nonearned" is directly conflicting with Malawian reciprocal and communal norms, and pursuing individual success may spark interpersonal tension, and jealousy. As Edward, a father of five from the rural villages explained when asked how people see individualized focused NGO interventions only benefiting some:

People can be jealous, but still it is the law of the NGO, that maybe the village has a 1000 people, but the NGO only wants to give to 20. It is a matter of getting the people to understand ... but still, the jealousy can be there.

The "law of the NGO" referred to here, relates to the NGOs' focus on helping certain individuals (e.g., mothers; girls; orphans). Edward's reflection is in line with what Piot (2010) and Classen (2013) note, NGOs interventions are seldom community based, rather specific individuals are chosen as they are defined as "as worthier" recipients. However, what qualifies as "worthy" may not necessarily make sense locally (see Adolfsson \& Moss, 2021). In addition, the help may not reach the "worthiest." For instance, Melina, a young single parent of three small children living in the rural villages, explains:

Mostly when the NGO money come, the NGOs always say that it should reach the people who are poor, the needy, the orphans', but because there is a lot of corruption in this village, you find that the money does not get to the ones who are supposed to receive them.

When asked if this corruption and unfair allocation of NGO money could lead to jealousy Melina answered that "Yes there can be jealousy because people can be surprised that 'Okay, many were invited to the NGO meeting but then only two or three received money.'" Here, the non-transparent and unequal distribution of NGO allocations is understood as unfair, and directly linked to sparking jealousy.

Some participants also brought up stories of overcoming NGOs' unequal practices. For example, Olivia, a Malawian former NGO-program director we met in Lilongwe, told us that one of the NGOs she had worked for had distributed maize bags, cooking oil and beans, to a designated number of households in a rural village. Upon checking in with the village Olivia explained, "The village chief had re-collected all the food, divided the lot in smaller portions and re-distributed it evenly to all households." Asking Olivia why the chief did this, she explained "Everybody has to get something!" noting that the chief only wanted to prevent jealousy from rising between households. While some would call this way of circumventing "the laws of the NGO" as creative (Swidler \& Watkins, 2017), it may also be interpreted as hidden transcripts of resistance (Scott, 1990). That is, when subordinated groups and individuals criticize and resist the dominant, in this case the NGOs' preset design, by reorganizing behind their back.

In this first theme, it is clear from the participants' accounts that the individualized and unequal focus of the NGOs contrasts with their intentional world and communal ways of 
life. That individualized interventions fuel interpersonal resentment and jealousy in the villages is a very critical issue that NGOs need to take seriously. When NGOs' "laws" are inconsistent with the social facts of the villagers; what they count as good, true, and effective, (exemplified by the chief redistributed the food) NGOs not only ignore their "beneficiaries" intentional world, they also actively promote their own individualistic ways of being, seeing and knowing that largely conflict with local values. In extension, such conflict can disrupt and damage the communal ways and vital norms of reciprocity, which tie the social fabric together.

\section{Theme 2: Ufiti and NGOs Individualized Approaches}

From the previous theme, the participants emphasize that "sudden" and "inexplicable" individual prosperity can lead to resentment and jealousy. The participants frequently also say that jealousy can lead to ufiti accusations and assaults. Apparent from these accounts is the discrepancy between the context where perceptions of $u$ fiti is prevalent and prominent in local lives, and the near complete disregard of such supernatural beliefs and expressions by the NGOs (as evident from the interview with the chief of the rural villages). As emphasized before, participants rarely explicitly link the NGOs individualized development initiatives and the phenomena of ufiti. However, as seen above, on the one hand, the participants frequently link individualized development and jealousy, and on the other, they emphasize the link between jealousy and ufiti. This theme is divided into three subthemes: individual development as a possible cause of ufit; ufiti and women; and avoiding ufiti.

\section{Subtheme 2.1. Individual Development as Possible Causes of Ufiti Assaults}

Across our data, participants tell us about $u f i t i$ and jealousy, often caused by individualized empowerment incentives. Often, these perceptions of ufiti are linked to school practices. Education and the possibilities that it enables are not available to all, as poorer families often do not have the possibility to pay for the school-fees and related school costs for all their children. Education is also a key activity sponsored in individualized and gendered development initiatives like empowerment approaches, making this an arena where inequality is very visible. The following quotes negotiate the relation between education, jealousy, and perceptions of ufiti. Chimango, a young man from the rural villages, talked about the consequences that may befall you if you manage to enroll higher education:

What happens is that others are not happy, they become jealous ... during school exams you don't see anything on the questionnaire, you just sleep ... when you are in class you don't see what the teacher has written on the chalkboard. Then you realize that something is wrong, that maybe you have been bewitched by someone in your home village ... because this jealousy happens when you have reached a certain level, when you are rich and different from them ... that is when the jealousy comes.

Like many of our participants, Chimango illustrates how being at a "higher level" than the fellow community members can put you at risk of kulodzedwa (being bewitched). Relatedly, we asked Melina, also from the rural villages, if people in the community would be jealous if her kids get higher education resulting in good jobs. She confirmed this: 
Because of illiteracy, that is why people can be jealous of the child, because the child is successful, and it is making the parents successful ... so because of that others can even kill [through ufiti spells] the parents or the child, because of jealousy.

Likewise, Lynda, an educated single woman in her thirties from the township, told us:

In 2001 back in my village, when I was studying with a friend behind our house, I found a plastic bag covered with soil and wrapped around charms, my friend screamed and my mother came and told us not to touch it. The village elders opened it and said it was strong charms, they said that the one who put it there did not want us not to succeed in school and that instead we should be dozing off during the lessons. We got scared and stopped using that place for studying.

When talking to Roshin, a young woman from the rural villages, she explained:

In this area, most of the youth, if they get educated, they leave to find a job in town. After moving, they start getting sick more often, while when they come back to the village they start feeling okay again. The witches are jealous because they have completed their studies. So, it is part of ufiti, because the witches make them ill, so they have to come back to the village and live the same life as everyone else is living.

Roshin's note on "having to live the same life as the others in the villages," corresponds with many of our participants' explanations on how ufiti works, as in "the witches are not happy when you are developed," "they want everyone to be at the same level." Many participants reiterated these stories of how people who made it to town had to return to their rural village after falling ill. Relatedly, Tanya, a single parent of a toddler, living in the rural villages, said she dropped out of school because she could not see what the teacher wrote on the blackboard, while outside of the school she could see properly. Tanya said she believed that someone in the villages had bewitched her. Now, she told us she worked with her mum, baking, and selling donuts at the nearby market.

As most NGO gendered empowerment work focuses on education, these findings show the potential link between such initiatives and ufiti accusations and assaults, and how the initiatives can worsen the situation for the individual in question rather than empower them. The findings also resonate with Lwanda's (2006, p. 262) qualitative and quantitative survey among Malawian secondary school students, which showed that "students may experience ufiti as the "jealousy" of their peers who are unable to get education." Similarly, Swidler and Watkins (2017, p. 111) recount one of their Malawian informants explaining: "people will use witchcraft [ufiti] against you if you go to get education ... this really happens. People with education will die in car accidents because someone cursed them." Because education is connected to development, and development-partly because of how NGO interventions often are designed - can result in individual progress, people who are "lucky" to be selected to partake in the NGO projects may simultaneously become more at risk.

\section{Subtheme 2.2. Ufiti and Women}

While anyone can be threatened by, and exposed to ufiti accusations and assaults, women are the most affected (Chilimampunga \& Thindwa, 2012; Mgbako \& Glenn, 2011), they are also the main target of NGOs individualized empowerment approaches (Rutherford, 2018). This is also emphasized in our study. Generally, across field settings, socio-economic status, gender, and age, participants note that women are more exposed and more vulnerable to $u$ fiti 
assaults. As Kamoto, a construction worker from the township put it "when witches see that a woman is successful, they cause death in her family, by bewitching the children." Susanna, a young single woman from the rural villages also explained how jealousy hits successful women:

Sometimes when people see that you are not lacking anything that's when they start being jealous. Most of the time they become jealous when they see you with a man, because they think like "when she is with that man definitely, she will become successful" ... ufiti is part of that jealousy

Here, Susanna's account shows how being with a successful man may put a woman in risk of becoming bewitched. Weston, a 26-year-old married father of two, who worked as a gardener for mzungu (translated as a wealthy white European man) in Lilongwe, said that his wife had been bewitched just months after giving birth to their first kid. Weston explained how the ufiti-curse had affected his wife "Last year my wife was bewitched, and it was so strange to me, because it was like madness ... she did not care, she had a three months baby but she did not care, she just went away." When asked why he thought his wife had been cursed he explained, "people saw me working for mzungu, thinking, "This guy he is working for mzungu! Maybe he gets a lot of money." Weston was sure one of their neighbors had cursed his wife out of jealousy of him working for an mzungu,

Because she was doing well, you see? Like, the neighbors thought that "ah, she goes to the market and buys chicken whereas us we just get cabbage" you see? "She gets tea whereas us we just get porridge" you see?

Though Weston earned the household's money working for an mzungu, his wife was the one targeted by ufiti assaults. These excerpts link women's vulnerability of ufiti assaults to being associated with successful men. In general, Malawian women largely rely on their husbands for economic support, thus his success becomes hers. A success that is more dangerous for her than for him. Several of the participants also talked about women gaining any sort of advantages being the easy target of ufiti forces. Amos, another young man working as a gardener for an mzungo in Lilongwe, explained:

In rural areas the girls are not educated, so if you as a young girl goes to school, people become jealous like "oh, why this one? Why is she special?" So they become jealous, and they can kill [using ufiti spells] her. Especially those girls in rural villages, they are scared.

As seen in many of the accounts, "the rural" is often pointed out as particularly strongly linked to ufiti assaults. As $85 \%$ of Malawi's population live in rural areas, family and kin tightly connect most people also in urban areas to "the rural." Therefore, the fear of ufiti does not necessarily disappear when moving to town, rather, the modern lifestyle connoted with "the urban" and the higher living standard, may make you more targeted. When talking to Pearl, a nurse originally from southern rural Malawi now living in a city, she told us "I was bewitched because people saw that I am now a nurse and I am now able to take care of myself." Pearl had suffered from paralysis in one of her legs, and as many of our participants, she reported that conventional school medicine had not cured her; instead, she had consulted a traditional healer, and told us that had helped.

In most of these quotes, particularly women and girls are targeted by ufiti-based violence, either because they are seen to benefit from being with successful men, or for creating their own success. This analysis shows how gender is powerfully linked to perceptions of $u f i t$, how being a woman makes you acutely more exposed, and more in need 
to maneuver ufiti-based violence. The analysis also shows the power inherent in being an mzungu, and the power inherent in working for an mzungu. Revealing how money, power, race, nationality, and whiteness is fundamentally associated with the inequality deeply rooted in colonial oppression.

\section{Subtheme 2.3. Avoiding Ufiti}

For people who deal with the unpredicted threat of $u$ fiti-based violence the danger is real. Especially participants from the rural villages were very worried about ufiti assaults, many feared for their children, and many expressed concerns for going out nighttime. As Blessings explained: "here in the village you can't walk at night, even the beer drinkers are scared. Everybody is at home after 6 pm." Dyman, an 18-year-old man also from the rural villages, told us, "During the night, I am scared to go out to pee, because that's the time when you can meet a witch." Accordingly, avoiding ufiti is crucial, and remains an important part of many people's lives. Many are forced to spend time, effort and money protecting themselves against it (Ashforth, 2015; Mbiti, 1990). There are different ways of protection; one manifest way is to share the benefits of the opportunities you receive, as Edward, from the rural villages explains:

If you help others with what you get, you can't get bewitched, nothing can happen to you. People can be jealous, for example if you have bought a car, but if there is a need in the village, maybe someone is sick, then they know that they can go to you for help.

Here, Edward notes that sharing and emphasizing the communal worth of your benefits—like driving someone ill to the hospital—will protect you from ufiti assaults. Relatedly, Lukas, a young Malawian NGO worker we met while we conducted fieldwork in the rural villages, told us how the chief in his home village, who for many years had scared him with his jealousy of his education, English-speaking skills, and progress, now, had turned around and become friendly:

You know what? Surprisingly the chief now even comes to chat with my family! Why? You know what? Every NGO that comes to the village they look for someone who is a bit educated and the chief is proud that I can talk to the NGOs, getting the village involved in different NGO activities.

Here, being the broker between the villages' chief and the NGOs, Lukas has made his education and English-language skills into something the village needs, something beneficial to all. Several participants brought up this notion of being able to help others with your education. Yet, many participants said it is not easy to escape ufiti assaults, and again, this concerns women more than men. Several participants talked about hiding prosperity as a way of avoiding ufiti-based violence. Lynda, who for many years had saved up money while working for international researchers and finally built her own house in the township, told us she was happy that the house was understood as belonging to a man, explaining,

Mostly people say that you are a prostitute and that you are benefiting from men, very few understand that it is your effort leading you to be successful. They become jealous, and they can bewitch you. Especially those people from your home village, when they come for a visit, and find that you are successful, they start being jealous, and bewitch you. So successful women when they go to their home village, they pretend they are not successful. 
For Lynda, the fact her house was not understood as hers protected her from others gossip, suspicions, resentment, envy, and ufiti accusations and assaults. This is in line with several scholars' work on ufiti assaults and gender-relations. Dolan (2002, p. 644) argues that $u$ fiti accusations against women are "associated with women transcending the boundaries of appropriate social behavior and hence, challenging their ascribed position within the social hierarchy." Given this premise, Malawian women-like women elsewhere-who aspire to rock the patriarchal status quo continuously hit the normative glass ceiling, often with backlashing effects that compromise their lives (Beard, 2017; Faludi, 1991). This in turn makes it safer for women to hide their success. In much the same way, Leistner (2014, p. 70) note that "The fear of arousing jealousy and being accused of ufiti causes people to avoid doing anything that will make them stand out by being uncommonly successful or fortunate." This thus entails that fear of jealousy and ufiti assaults may be an active hindrance to buying into the logic of individualized development/empowerment, as well as the breach this may represent with communally oriented lives. Relatedly, Prince, a bike-taxi driver from the township explained to us why women in rural areas avoid progress:

In rural areas, $\ldots$ if they see a woman with great ambitions, they bewitch her.

Because of this, most people in rural areas don't bother to build good houses for the fear of being attacked by ufiti

Here, Prince echoes the previous sentiments that the witches do not like women with ambitions. This fear of becoming the target of others' jealousy and related ufiti-accusations allegedly makes_-particularly rural Malawian women — hesitant to pursue and show individual advancements.

In this second theme, the participants have shown different consequences that may follow from pursuing and practicing the type of individual progress and development that NGOs promote. This link between individualism and jealousy on the one hand, and between jealousy and ufiti on the other, may have critical consequences for the NGOs' "beneficiaries." Through the decolonial and feminist cultural psychological lens our analysis speaks to the coloniality inherent in dominant assumptions of being that operate as natural standards (Adams et al., 2015). In this analysis, particularly women and girls are affected by Western standards of individuality and self-actualization, clashing with their communal intentional world. The women and girls NGOs in Malawi aim to empower areas most women and girls elsewhere-stuck in a patriarchal system that relentlessly pulls them down. Therefore, the NGOs ignorance of women and girls' social facts and norms that maneuver and navigate by, may on the contrary disempower them by making them more exposed to patriarchal dominance and ufiti-accusations and assaults. Ultimately, when NGOs ignore the intentional worlds of their "beneficiaries", they may in line with their individualistic logic, see Malawian women and girls who avoid individual progress as failing to become empowered and developed.

\section{Discussion}

In realities where the fear of supernatural forces like ufiti permeate all levels of life; where prosocial behavior, communal values, and reciprocal norms and obligations protect people from both poverty- and ufiti-related dangers; where independent individual progress, expansion, and unshared prosperity are associated with asocial, selfish, greedy behavior, and directly linked to harmful acts of ufiti; then, pursuing and practicing such 
behavior is perceived as both immoral and dangerous for individuals and communities. Thus, when NGOs promote individualized development, singling out and "empowering" specific people to seek individual self-actualization and progress they risk doing so in opposition with peoples' understandings of their social facts and intentional world. This interfering is particularly dangerous for women and girls, as they are more exposed to ufiti accusations and assaults.

The link between individualized gendered development/empowerment, and resentment, jealousy, and perceptions of ufiti, as unpacked in this article, is not recognized, or incorporated in the work of many NGOs operating in Malawi (Chilimampunga \& Thindwa, 2012). Presumably because the role of spirituality, ufiti and the occult is largely avoided in development programming (Smith et al., 2017). This neglect of the Others cosmology, we argue, is a matter of spiritual Othering; a heritage and continuance of colonial Eurocentric knowledge production, in which the Others' spiritual ontologies are marginalized, ignored, and/or written off as backward and "non-real." We argue that the NGOs' spiritual Othering of the Malawian phenomena of ufiti, is, coupled with their pre-set and vertical way of implementing individualized development are manifestations of coloniality, which is highly problematic for the NGOs "beneficiaries." Furthermore, as the individualistic paradigm is so prominent within many conventional Euro-American psychological orientations, and given the fact that many of their theories and practices disregard and/or pathologizes African experiences of spirituality, many serve as promoters of coloniality of individualism and spirituality.

Returning to Shweder's (1990) intentional worlds and his metaphor of the "weed" it becomes crucial to recognize and act on the fact that a dandelion may be a weed in some places but not in others. This entails that what is regarded as justified, valid, and true, is socially and culturally constructed and decided (Shweder, 1990), which should be a fundamental aspect in all intercultural collaboration, as development practitioners and psychologists. Nevertheless, our argument also goes further than that. Where developmental approaches and psychology needs to be mindful of different intentional worlds particularly in intercultural collaborations, there is also a need within the broader spectra of psychology to a much larger extent to acknowledge both current and historical contexts (see for example Sullivan, 2020). By applying a denaturalization-strategy (see Adams et al., 2015), unburdened individualism dismantles as manifestations of Western coloniality, and as an inversion of communal norms and morals of reciprocity that may be dangerous for individuals and groups. As such, pursuing and practicing Western individualism is not familiar for many people in many places, and should not be treated and promoted as a universal "natural," neither by development practitioners nor by psychologists.

We echo Burr and Dick (2017, p. 66) social constructionist stance that "the social context in which we live is not just a set of important variables to be taken into consideration when trying to understand behavior. Without the social realm people as we know them would not exist at all; we become human by virtue of taking part in social life." The communal way of life in Malawi may thus also reflect life elsewhere to larger extents than psychology as a general discipline recognizes. Along with Burr and Dick (2017, p. 66) we criticize the focus on individualism over social embeddedness in many established psychological disciplines, and their individualistic focus that "celebrates and privileges the unique, self-contained person." The fields of global development and psychology should, we argue, move towards meaningful engagement with contexts and intentional worlds in their general workings, to a whole other level than the ones these fields are currently engaging in. 


\section{Limitations of the Study}

The study has important limitations that we want to emphasize. First, in two of the three field settings, we recruited a convenience sample (in the rural villages however, we interviewed all households). Efforts were made to reach a diverse sample, with variations in age, gender, positions, and backgrounds, making the stances and experiences varied. That conceptualizations of ufiti came up so frequently across this broad sample is interesting and resonates with the previous finding that $87 \%$ of household heads in Malawi reported that $u$ fiti is present in their communities (Chilimampunga \& Thindwa, 2012). Second, for some of the participants-particularly the older ones in the rural villages - the topic of ufiti was often avoided, so getting them to engage in discussions of perceptions of $u$ fiti and its consequences was sometimes difficult. Wanda's longterm relationship building with participants in the rural villages proved very helpful. Third, with the entire colonial, race, and class connotations inherent in being an mzunga, the first author's presence in especially the township and rural villages proved challenging and probably affected what participants have shared with us, and in turn how we have interpreted the material. Wanda's lengthy stay both in the township and in the rural villages prior to the first author arrival proved invaluable for establishing report, trust and understanding of the project, and stresses the imperative need, as well as joys of collaborating across class/race/nationality and global South and North power structures in research and in development practices. Lastly, depending on translations warrants discussions of what may be lost in translation. Still, Wanda enabled access and sensitivity to the context that would otherwise not have been possible.

\section{Future Studies}

In our study, we have explored the participants' accounts of perceptions of ufiti and individualized development/empowerment, but future studies could conduct deep ethnographic research over time to get at ufiti practices. It would also be interesting to engage more extensively with the "universalist" individualized approaches of the NGOs and donors, getting at their narratives of how they see context and culture. A decolonial, feminist, and cultural psychology lens would be a valuable approach for both research directions.

Funding Open access funding provided by University of Oslo (incl Oslo University Hospital). The Norwegian Research Council funded the study.

\section{Declarations}

Ethics Approval Research permits were granted by the National Commission for Science and Technology in Malawi (NCST); the local District Council, the village authorities, as well as by the Norwegian Centre for Research Data (NSD).

Consent to Participate All participants in this study have read and signed consent to participate. The study is approved by the Norwegian Center for Research Data (NSD), who "ensure that data about people and society can be collected, stored and shared, both safely and legally."

Consent for Publication All participants in this study have read and signed consent to participate, and been informed that the material will be used for publications.

Conflict of Interest The authors declare no competing interests. 
Open Access This article is licensed under a Creative Commons Attribution 4.0 International License, which permits use, sharing, adaptation, distribution and reproduction in any medium or format, as long as you give appropriate credit to the original author(s) and the source, provide a link to the Creative Commons licence, and indicate if changes were made. The images or other third party material in this article are included in the article's Creative Commons licence, unless indicated otherwise in a credit line to the material. If material is not included in the article's Creative Commons licence and your intended use is not permitted by statutory regulation or exceeds the permitted use, you will need to obtain permission directly from the copyright holder. To view a copy of this licence, visit http://creativecommons.org/licenses/by/4.0/.

\section{References}

Adams, G., Dobles, I., Gómez, L. H., Kurtiş, T., \& Molina, L. E. (2015). Decolonizing psychological science: introduction to the special thematic section. PsychArchives. https://doi.org/10.23668/psycharchives. 1766

Adams, G., \& Estrada-Villalta, S. (2017). Theory from the South: a decolonial approach to the psychology of global inequality. Current Opinion in Psychology, 18, 37-42. https://doi.org/10.1016/j.copsyc.2017. 07.031

Adams, G., Estrada-Villalta, S., \& Ordóñez, L. H. G. (2017). The modernity/coloniality of being: hegemonic psychology as intercultural relations. International Journal of Intercultural Relations, 62, 13-22. https://doi.org/10.1016/j.ijintrel.2017.06.006

Adjei, S. B. (2015). Assessing women empowerment in Africa: a critical review of the challenges of the gender empowerment measure of the UNDP. Psychology and Developing Societies, 27(1), 58-80. https://doi.org/10.1177/0971333614564740

Adjei, S. B. (2019). Conceptualising personhood, agency, and morality for African psychology. Theory \& Psychology, 29(4), 484-505. https://doi.org/10.1177/0959354319857473

Adolfsson, J. S., \& Madsen, O. J. (2020). "Nowadays there is gender": "doing” global gender equality in rural Malawi. Theory \& Psychology, 30(1), 56-76. https://doi.org/10.1177/0959354319879507

Adolfsson, J. S. \& Moss, S. M. (2021). Making meaning of empowerment and development in rural Malawi: international individualism meets local communalism. Manuscript submitted for publication.

Anderson, E. (2015). Gender, HIV and risk: navigating structural violence. Palgrave Macmillian.

Ashforth, A. (2015). Witchcraft, justice, and human rights in Africa: cases from Malawi. African Studies Review, 58(1), 5-38. https://doi.org/10.1017/asr.2015.2

Baloyi, L., \& Ramose, M. B. (2016). Psychology and psychotherapy redefined from the viewpoint of the African experience. Alternation Journal, 18, 12-35. Retrieved from https://journals.ukzn.ac.za/index. $\mathrm{php} / \mathrm{soa} / \mathrm{article} / \mathrm{view} / 1352$

Beard, M. (2017). Women \& power: a manifesto. Profile Books.

Braun, V., \& Clarke, V. (2006). Using thematic analysis in psychology. Qualitative Research in Psychology, 3(2), 77-101. https://doi.org/10.1191/1478088706qp063oa

Bulhan, H. A. (2015). Stages of colonialism in Africa: from occupation of land to occupation of being. PsychArchives. https://doi.org/10.23668/psycharchives.172

Burr, V. (2015). Social constructionism. Routledge.

Burr, V., \& Dick, P. (2017). Social constructionism. In B. Gough (Ed.), The Palgrave handbook of critical social psychology (pp. 59-80). Palgrave Macmillan.

Chilimampunga, C., \& Thindwa, G. (2012). The extent and nature of witchcraft-based violence against children, women and the elderly in Malawi. The Royal Norwegian Embassy, Lilongwe, Malawi. Retrieved from http://www.whrin.org/wpcontent/uploads/2014/06/Witchcraft-report-ASH.pdf

Classen, L. S. (2013). Not “just staying”: how health and development programming is reshaping the past, present and future for rural youth in Malawi. (Doctoral Dissertation, University of Toronto). Retrieved from https://central.baclac.gc.ca/.item?id=TCOUT43497\&op=pdf\&app=Library\&oclc_number=1033167554

Davar, B. V. (2020). Gender, depression and emotion: arguing for a de-colonized psychology. In M. Anand (Ed.), Gender and mental health: combining theory and practice (pp. 19-32). Springer.

Dhar, A. (2020). The slippery and the sane: decolonizing psychology through a study of the Indian girlchild. Feminism \& Psychology, 30(3), 391-414. https://doi.org/10.1177/0959353520922419

Dolan, C. S. (2002). Gender and witchcraft in agrarian transition: the case of Kenyan horticulture. Development and Change, 33(4), 659-681. https://doi.org/10.1111/14677660.00274

Edriss, A. K., \& Chiunda, C. (2017). Interfaces between road infrastructure and poverty in Africa: the case of Malawi, 1994-2013. Journal of Social Economics Research, 4(1), 9-21. https://doi.org/10.18488/ journal.35.2017.41.9.21. 
Englund, H. (1996). Witchcraft, modernity and the person: the morality of accumulation in Central Malawi. Critique of Anthropology, 16(3), 257-279. https://doi.org/10.1177/0308275X9601600303

Englund, H. (2007). Witchcraft and the limits of mass mediation in Malawi. Journal of the Royal Anthropological Institute, 13(2), 295-311. https://doi.org/10.1111/j.14679655.2007.00429.x

Faludi, S. (1991). Backlash: the undeclared war against American women. Crown.

Federici, S. (2018). Witches, witch-hunting, and women. PM Press.

Ferguson, J. (2006). Global shadows: Africa in the neoliberal world order. Duke University Press.

Golooba-Mutebi, F. (2005). Witchcraft, social cohesion and participation in a South African village. Development and Change, 36(5), 937-958. https://doi.org/10.1111/j.0012155X.2005.00442.x

Holdstock, T. L. (2000). Re-examining psychology: critical perspectives and African insights. Routledge.

Kessi, S., \& Boonzaier, F. (2018). Centre/ing decolonial feminist psychology in Africa. South African Journal of Psychology, 48(3), 299-309. https://doi.org/10.1177/0081246318784507

IMF. (2017). Malawi Economic Development Document. (IMF Country Report No. 17/184). Retrieved from International Monetary Fund Washington, D.C.: https://www.imf.org/en/Publications/CR/Issues/2017/ 07/05/Malawi-EconomicDevelopmentDocument-45037

Ivey, G., \& Myers, T. (2008). The psychology of bewitchment (Part I): a phenomenological study of the experience of bewitchment. South African Journal of Psychology, 38(1), 54-74. https://doi.org/10. $1177 / 008124630803800104$

Johnson, J. (2018). Feminine futures: female initiation and aspiration in matrilineal Malawi. Journal of the Royal Anthropological Institute, 24(4), 786-803. https://doi.org/10.1111/14679655.12917

Kurtis, T., \& Adams, G. (2013). A cultural psychology of relationship: toward a transnational feminist psychology. In M. K. Ryan \& N. R. Branscombe (Eds.), The Sage handbook of gender and psychology (pp. 251-269). SAGE Publications.

Leistner, E. (2014). Witchcraft and African development. African Security Review, 23(1), 53-77. https:// doi.org/10.1080/10246029.2013.875048

Lwanda, J. (2005). Politics, culture and medicine in Malawi. Kachere Series.

Lwanda, J. (2006). Kwacha: the violence of money in Malawi's politics, 1954-2004. Journal of Southern African Studies, 32(3), 525-544. https://doi.org/10.1080/03057070600830482

Makhubela, M. (2016). "From psychology in Africa to African psychology": going nowhere slowly. Psychology in Society, 52, 1-18. https://doi.org/10.17159/23098708/2016/n52a1

Maldonado-Torres, N. (2007). On the coloniality of being: contributions to the development of a concept. Cultural Studies, 21(2-3), 240-270. https://doi.org/10.1080/09502380601162548

Mbembe, A. (2001). On the postcolony. University of California Press.

Mbiti, J. S. (1990). African religions \& philosophy. Heinemann.

Mgbako, C. A., \& Glenn, K. (2011). Witchcraft accusations and human rights: case studies from Malawi. George Washington International Law Review, 43(3), 389-418.

Mies, M. (2014). Patriarchy and accumulation on a world scale: women in the international division of labour. Zed Books.

Mignolo, W. D. (2007). Delinking: The rhetoric of modernity, the logic of coloniality and the grammar of decoloniality. Cultural Studies, 21(2-3), 449-514. https://doi.org/10.1080/09502380601162647

Mkhize, N. (2004). Psychology: an African perspective. In K. Raele., N. Duncan., N. Mkhize., P. Kiguwa \& A. Collins (Eds.), Self, community \& psychology. (4-1). UCT Press.

Moss, S. M. \& Hajj, M. H. (2020). Keepers of local know-how in conflict: conversations between research assistant and researcher. In Y. Acar, S. M. Moss and Ö. M. Uluğ (Eds.), Researching peace, conflict and power in the field: Methodological challenges and opportunities. Springer Nature.

Murrey, A. (2017). Decolonising the imagined geographies of 'witchcraft.' Third World Thematics: A TWQ Journal, 2(2-3), 157-179. https://doi.org/10.1080/23802014.2017.1338535

NSO. (2019). 2018 Malawi Population and Housing Census: Main Report. Retrieved from https://malawi. unfpa.org/sites/default/files/resourcepdf/2018\%20Malawi\%20Population\%20and\%20Housing\%20Census\% 20Man\%20Report $\% 20 \% 281 \% 29$.pdf

Nwoye, A. (2013). A theory of the gates of stress in everyday life: a challenge to eurocentrism. Retrieved from https://thediscourseunit.files.wordpress.com/2016/05/tansania-nigeria-886900.pdf

Nwoye, A. (2015). What is African psychology the psychology of ? Theory \& Psychology, 25(1), 96-116. https://doi.org/10.1177/0959354314565116

Nwoye, A. (2017). A postcolonial theory of African Psychology: a reply to Kopano Ratele. Theory \& Psychology, 27(3), 328-336. https://doi.org/10.1177/0959354314565116

Ogbonnaya, A. O. (1994). Person as community: an African understanding of the person as an intrapsychic community. Journal of Black Psychology, 20(1), 75-87.

Paass, S. (2016). Chichewa-English/English-Chichewa Dictionary. Oxford University Press. 
Piot, C. (2010). Nostalgia for the future: West Africa after the Cold War. University of Chicago Press.

Pot, H. (2019). INGO behavior change projects: culturalism and teenage pregnancies in Malawi. Medical Anthropology, 38(4), 1-15. https://doi.org/10.1080/01459740.2019.1570187

Quijano, A. (2000). Coloniality of power and Eurocentrism in Latin America. International Sociology, 15(2), 215-232. https://doi.org/10.1177/0268580900015002005

Ratele, K. (2017). Four (African) psychologies. Theory \& Psychology, 27(3), 313-327. https://doi.org/ $10.1177 / 0959354316684215$

Rutherford, A. (2018). Feminism, psychology, and the gendering of neoliberal subjectivity: from critique to disruption. Theory \& Psychology, 28(5), 619-644. https://doi.org/10.1177/0959354318797194

Sagner, A., \& Mtati, R. Z. (1999). Politics of pension sharing in urban South Africa. Ageing \& Society, 19(4), 393-416. https://doi.org/10.1017/S0144686X99007424

Scott, J. C. (1990). Domination and the arts of resistance: Hidden transcripts. Yale University Press.

Segalo, P., \& Fine, M. (2020). Under lying conditions of gender-based violence-Decolonial feminism meets epistemic ignorance: Critical transnational conversations. Social and Personality Psychology Compass, 14(10), 1-10. https://doi.org/10.1111/spc3.12568

Shweder, R. A. (1990). Cultural psychology: what is it? In J. Stigler, R. Shweder, \& G. Herdt (Eds.), Cultural psychology: essays on comparative human development (pp. 1-46). Cambridge University Press.

Shweder,R. A. (2006). John Searleona witch hunt:acommentary onJohnR. Searle'sessay 'Socialontology: Some basic principles'. Anthropological theory, 6(1), 89-111. https://doi.org/10.1177/1463499606061739

Smith, J. H. (2008). Bewitching development: witchcraft and the reinvention of development in neoliberal Kenya. University of Chicago Press.

Smith, T. A., Murrey, A., \& Leck, H. (2017). 'What kind of witchcraft is this?' development, magic and spiritual ontologies. Third World Thematics: A TWQ Journal, 2(2-3), 141-156. https://doi.org/10.1080/23802014. 2017.1411209.

Sullivan, D. (2020). Social psychological theory as history: outlining the critical historical approach to theory. Personality and Social Psychology Review, 24(1), 78-99. https://doi.org/10.1177/1088868319883174

Swidler, A. (2013). African affirmations: the religion of modernity and the modernity of religion. International Sociology, 28(6), 680-696. https://doi.org/10.1177/0268580913508568

Swidler, A., \& Watkins, S. C. (2017). A fraught embrace: the romance and reality of AIDS altruism in Africa. Princeton University Press.

Tambulasi, R., \& Kayuni, H. (2005). Can African feet divorce western shoes? the case of 'ubuntu' and democratic good governance in Malawi. Nordic Journal of African Studies, 14(2), 147-161.

Tembo, M. S. (1993). The witchdoctors are not wrong: The future role and impact of African psychology on individual well-being. Paper presented at the Annual Meeting of the African Studies Association held in Boston. Retrieved from https://wp.bridgewater.edu/mtembo/wpcontent/uploads/sites/380/2016/11/ WitchcraftPaper.pdf

The Ministry of Gender, C., Disability and Social Welfare Malawi. (2013). Gender Equality and Women Empowerment (GEWE) programme. Retrieved from http://www.gender.gov.mw/index.php/2013-081917-29-14/gender-equality-and-women-empowerment-programme

UNDP. (2016). Accelerating gender equality and women's empowerment in Africa. Retrieved from https:// econpapers.repec.org/paper/agsundpar/267638.htm

Publisher's Note Springer Nature remains neutral with regard to jurisdictional claims in published maps and institutional affiliations. 